\title{
Water quality index of the ground water of bitumen deposit impacted farm settlements using entropy weighted method
}

\author{
E. O. Fagbote $\cdot$ E. O. Olanipekun $\cdot$ H. S. Uyi
}

Received: 9 February 2012/Revised: 27 September 2012/ Accepted: 9 December 2012/Published online: 10 January 2013

(c) CEERS, IAU 2013

\begin{abstract}
Ground water of the farm settlements in the bitumen deposit area of Western Nigeria were tested for $\mathrm{pH}$, conductivity, turbidity, total dissolved solid, sulphate, phosphate, nitrogen nitrate, chloride, alkalinity, total hardness, calcium, magnesium, sodium, potassium and total coliform in the dry season (March) and rainy season (August) of years 2008 and 2009 using atomic absorption spectrometer and standard analytical methods. Conductivity, $\mathrm{pH}$, turbidity, phosphate ions and total coliform values obtained in some of the wells were out of the recommended range for drinking water. Water quality index analysis was carried out using information entropy method. Water quality index of the wells when compared with the permissible limits of international standards, ranked the bore hole as 'excellent' in the dry season of year 2009 and just 'good' in the rainy season of the same year. Ground water sampling stations were ranked extremely poor at least once out of the four seasons considered. Water quality index ranking also showed that the quality of the wells declined over the years. The correlation coefficient matrix $(p<0.05)$
\end{abstract}

\author{
E. O. Fagbote $(\bowtie) \cdot$ E. O. Olanipekun \\ Department of Chemistry, University of Ado-Ekiti, \\ Ado-Ekiti, Nigeria \\ e-mail: bunmifag@yahoo.com \\ E. O. Olanipekun \\ e-mail: eddylapek@yahoo.com \\ Present Address: \\ E. O. Fagbote \\ P.O. 6983, Chapel of Victory, 29 Victory Avenue, \\ Elekahia, Port Harcourt, Nigeria \\ H. S. Uyi \\ Institute of Pollution Studies, Rivers State University of Science \\ and Technology, Port Harcourt, Nigeria \\ e-mail: uyihansylva@yahoo.com
}

of water quality index and the parameters showed significant relationships between water quality index and total coliform (0.99), total dissolved solids and conductivity (0.96), hardness and $\mathrm{Ca}^{2+}(0.68)$, hardness and $\mathrm{Mg}^{2+}$ (0.75). Water quality index also showed moderate significant relationship with total dissolved solid, conductivity and $\mathrm{N}-\mathrm{NO}_{3}{ }^{-}$. High concentration of total coliform in most of the shallow wells in the environment, due to bitumen deposit, renders them unfit for human consumption unless properly treated.

Keywords Correlation coefficient - Dry season · Parameters · Permissible limits · Rainy season $\cdot$ Wells

\section{Introduction}

A key prerequisite in environmental protection policy making is water quality related data. The usual way to organize a wide set of data is to apply indexes and indicators as a tool that summarize many parameters. This makes it possible to reduce numerous data to an acceptable amount of information and the meaning is still preserved (Veljkovic et al. 2008). Water quality index is one of the most effective tools used in passing information on the quality of water to the concerned citizens and policy makers (Atulegwu and Njoku 2004). Therefore, it is an important parameter for the assessment management of water (Yisa and Jimoh 2010). Water quality monitoring helps in evaluating the nature and extent of pollution control required, and effectiveness of pollution control measures already in existence. It also helps in drawing the water quality trends and prioritising pollution control efforts (Bhardwaj 2005).

The qualities of water bodies vary widely depending on the location and environmental factors. Some of the factors 


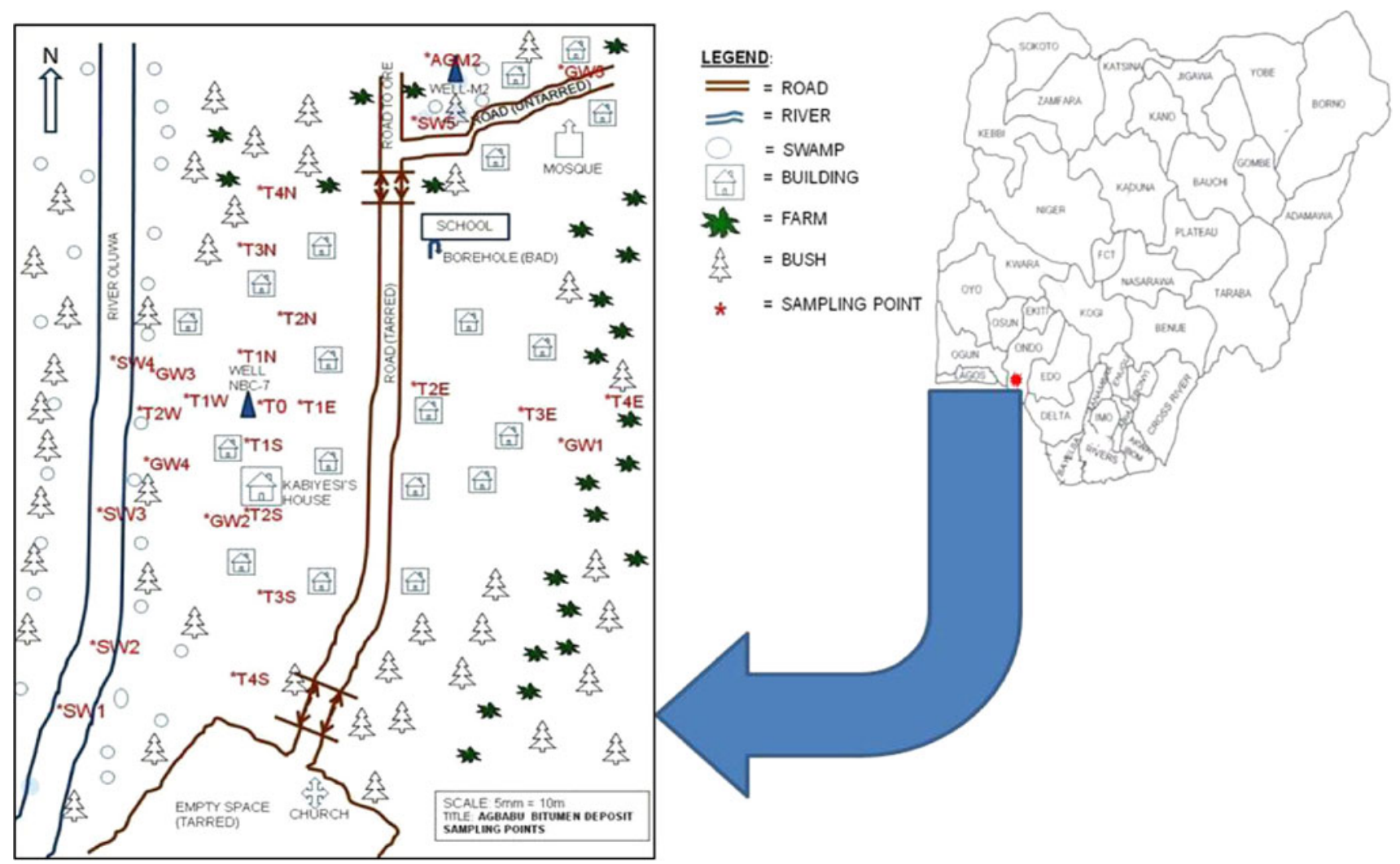

Fig. 1 Map of Nigeria showing the sampling points

determining the qualities of surface waters and ground waters are the chemical composition of the underlying rocks, soil formations and the length of time that the water body has been trapped underground (Faniran et al. 2001). Other causes of water pollution include sewage and wastes, infectious agents, chemicals, mineral substances, sediments, radioactive substances and thermal pollution. Anthropogenic activities that may also result in water pollution include agriculture, irrigation, urbanization, mining, fire and industrialization (Asonye et al. 2007). To ensure that the water quality is being maintained or restored at the desired level, it is important to monitor it on a regular basis (Mohamad et al. 2007).

The Nigerian bitumen is believed to have similar composition as the light crude oil, that is, hydrogen, carbon, and minor amount of sulphur and oxygen (Akinmosin et al. 2009). It is believed to have formed from biodegradable and water washing of light crude. The probable reserve of bitumen and heavy oil in the entire Nigerian belt is about $120 \times 4.3 \mathrm{~km}$ (Adegoke and Ibe 1982; Oboh et al. 2006), spreading along the bitumen belt stretching from Lagos, Ogun through to Ondo and Edo State. Nigeria has also a reserve of 30-40 billion barrels of bitumen (Oguntimehin and Ipinmorroti 2007). Agbabu and Temidire are farm settlements in the Nigerian bitumen deposit area which is about $210 \mathrm{~km}$ to Lagos in the south-western part of
Nigeria. Agbabu is a village of about 400 inhabitants in the coordinates of E004 $48-49^{\prime}$ and $\mathrm{N}^{\circ} 6^{\circ} 34-36^{\prime}$, while Temidire is a smaller village of about 200 people located in the coordinates $\mathrm{E} 004^{\circ} 49-50^{\prime}$ and $\mathrm{N}^{\circ} 6^{\circ} 36-37^{\prime}$, which is about $2 \mathrm{~km}$ to Agbabu (Fig. 1). Temperature remains moderate throughout the year in the area with the minimum around $24{ }^{\circ} \mathrm{C}$ and the maximum around $33{ }^{\circ} \mathrm{C}$. The two distinct seasons in the year are rainy and dry. The rainy season is at its peak from July to the middle of September while the dry season is from January to March.

Determination of physico-chemical parameters and trace metal contents of drinking water samples in Akure, Ondo State, Nigeria has been reported (Abulude et al. 2007). Research on some physico-chemical characteristics and heavy metal profiles of Nigerian rivers, streams and waterways has been published (Asonye et al. 2007). The distribution of polycyclic aromatic hydrocarbons (PAHs) in the surface soils and water from the vicinity of Agbabu bitumen field of South Western Nigeria has been investigated (Olajire et al. 2007). Assessment of surface water quality of the Ceyhan river basin, Turkey has been reported (Tanriverdi et al. 2009). Water quality status of dugouts from five districts in Northern Ghana with implications for sustainable water resources management in a water stressed tropical savannah environment has also been reported (Cobbina et al. 2009). 
The distribution of $n$-alkanes in soil and water samples collected near Agbabu bitumen field of south-western Nigeria has been investigated (Olajire et al. 2008). Environmental implications of bitumen seep induced pollution in parts of Ogun state, south-western Nigeria has been studied (Adewole 2010). Speciation of heavy metals in soil of bitumen impacted area of Western Nigeria has been reported (Fagbote and Olanipekun 2010a).

A combination of factors has prevented the exploitation of bitumen in Nigeria to date. These factors include lack of commitment by government, politics, availability of crude oil in the country, consideration of environmental effects, and cost of production. The most important is the environmental effects that may pose threat to both physical and biological components in the area of occurrence (Akinmosin et al. 2009). Physical components are soil, sediment and water, while biological components are plants, animals and fish. It is therefore, imperative to know the pre-exploitation status of pollution in soil, sediment, ground water, surface water and plant in the environment. This will make assessment of the contribution of anthropogenic activities to environmental contamination that may be associated with mining project when it eventually takes off easy and effective. The need for this research arose because no study has been reported on assessment of ground water quality of Agbabu bitumen deposit area, Western Nigeria. The data obtained could be used as a baseline data on the environment when bitumen exploitation commences.

This study involved determination of water quality index (WQI) of Agbabu and Temidire bitumen deposit area ground water with entropy weighted method. This method is preferred to the common method of assigning weights to the parameters according to researchers experience in which useful and valuable information about the water quality can get lost. Entropy weight makes WQI perfect and makes the assessment results more reasonable. It computes the ground water quality ranks and can easily illustrate the comparison between two samples in the same rank (Pei-yue et al. 2010b).

Ground water samples were collected from a bore hole and hand dug wells at Agbabu and Temidire farm settlements in Ondo State, Western Nigeria. Samples were collected in the dry season (March 2008 and 2009) and rainy season (August 2008 and 2009) and tested for the following physico-chemical parameters: $\mathrm{pH}$, conductivity, turbidity, salinity, total dissolved solid, sulphate, phosphate, nitrogen nitrate, chloride, alkalinity, total hardness, calcium, magnesium, sodium, potassium and total coliform. Hand dug wells and bore hole are both considered as ground water in this study because ground water is the water that collects or flows beneath the Earth's surface, filling the porous spaces in soil, sediment, and rocks and can be accessed through wells and bore holes.

\section{Materials and methods}

\section{Sampling}

Samples were collected from six ground water locations in the (AGGW1, AGGW2, AGGW3, AGGW4, AGBH located in Agbabu village, AGSWM2 located in Temidire village) in the dry and rainy seasons of years 2008 and 2009.

Sampling points were geo-located with Geographical Position System (GPS) to ensure consistency. Samples for water chemistry were collected in $500 \mathrm{ml}$ plastic jugs and kept at ambient temperature. Ambient temperature, water temperature and $\mathrm{pH}$ for the water samples were taken at the collection points. Reagent blanks were used in all analyses to check reagent impurities and other environmental contaminations during analyses. Analytical grade reagents were used for all analyses. All reagents were standardized against primary standards to determine their actual concentrations. All glasswares used were washed with detergent and rinsed with water before use. Instruments used were Horiba Water Checker (Model U-10), Lovibond CM-21 Tintometer and Thermo Elemental M-Series Atomic Absorption Spectrometer (AAS). These instruments were calibrated before use. Quality checks were also performed on the instruments by checking the absorbance after every ten sample runs tools and work surfaces were carefully cleaned for each sample. Minimum of triplicate readings were taken to check precision of the analytical method and instrument.

$\mathrm{pH}$, conductivity and turbidity were measured using Horiba Water Checker (Model U-10) after calibrating the instrument with the standard Horiba solution. Total dissolved solid (TDS) was measured with a Lovibond CM-21 Tintometer. Sulphate determination was by the turbidimetric method. Phosphate was determined using the stannous chloride method. Nitrate measurement was by the Brucine method (APHA 1985). Chloride was determined by the argentometric titration method (APHA 1985). Total alkalinity determination involved the titration of $50 \mathrm{ml}$ sample, containing 5 drops methyl orange indicator with $0.02 \mathrm{~N} \mathrm{H}_{2} \mathrm{SO}_{4}$ solution. The EDTA titration method was used in determining total hardness. The EDTA titration method (APHA 1985) was used in determining calcium. Magnesium concentration was determined by the calculation method as follows:

$\mathrm{Mg} \mathrm{mg} / \mathrm{l}=$ [total hardness as $\mathrm{CaCO}_{3}-$ calcium hardness as $\left.\mathrm{CaCO}_{3}\right] \times 0.243$.

Sodium $\left(\mathrm{Na}^{+}\right)$and potassium $\left(\mathrm{K}^{+}\right)$concentrations in the water were measured using Thermo Elemental M-Series Atomic Absorption Spectrometer (AAS).

Total coliform bacteria were estimated in water samples by multiple tube fermentation method called the most probable number (MPN) (Collins and Lyne 1980). 
The MPN test was done by using specified number of test tubes containing Mac Conkey broth medium and sample volumes. After incubation at $37{ }^{\circ} \mathrm{C}$ for $24-48 \mathrm{~h}$, positive tubes were examined for acid and gas production indicative of growth of total coliform bacteria. The MPN number of coliforms present was determined statistically (Collins and Lyne 1980). The MPN technique involved three major steps namely presumptive, confirmatory and completed tests (Gruickshank et al. 1984).

Computation of WQI using the concept of information entropy (Pei-yue et al. 2010a, 2010b):

Step 1-Assigning an entropy weight to each parameter

To calculate entropy weight: If there are ' $z$ ' water samples $(i=1,2,3 \ldots z)$. Each sample has ' $t$ ' evaluated parameters $(j=1,2,3 \ldots t)$. Then, Eigen value matrix $X$ can be constructed as shown in Eq. 1:

$X=\left\{\begin{array}{cccc}X_{11} & X_{12} & \ldots & X_{1 t} \\ X_{21} & X_{22} & \ldots & X_{2 t} \\ \cdot & \cdot & \ldots & \cdot \\ \cdot & \cdot & \ldots & \cdot \\ \cdot & \cdot & \ldots & \cdot \\ X_{z 1} & X_{z 2} & \ldots & X_{z t}\end{array}\right\}$

The feature indexes may be divided into efficiency type, cost type, fixed type and interval type.

For efficiency type, the construction function of normalization $\left(Y_{i j}\right)$ is given in Eq. 2:

$Y_{i j}=\frac{x_{i j}-\left(x_{i j}\right)_{\min }}{\left(x_{i j}\right)_{\max }-\left(x_{i j}\right)_{\min }}$

where $Y_{i j}$ is the construction function of normalization for an evaluated parameter $(j)$ in a particular water sample $(i)$. $X_{i j}$ is the original water quality analysis data, $\left(X_{i j}\right)_{\min }$ and $\left(X_{i j}\right)_{\max }$ are the minimum and maximum of each index in the original water analysis data.

In calculating the weights, the initial matrix must be transformed to eliminate the error caused by different dimensions and different units. After transformation, the standard grade matrix $Y$ can be obtained as shown in Eq. 3 .

$Y=\left\{\begin{array}{cccc}Y_{11} & Y_{12} & \ldots & Y_{1 t} \\ Y_{21} & Y_{22} & \ldots & Y_{2 t} \\ \cdot & \cdot & \ldots & \cdot \\ \cdot & \cdot & \cdots & \cdot \\ \cdot & \cdot & \cdots & \cdot \\ Y_{z 1} & Y_{z 2} & \ldots & Y_{z t}\end{array}\right\}$

The ratio of index value of the $j$ index and in $i$ sample is given in Eq. 4

$P_{i j}=y_{i j} / \sum_{i=1}^{z} y_{i j}$

The information entropy $\left(E_{j}\right)$ is given by the following formula,
$E_{j}=(1 / \ln Z) \times \sum_{i=1}^{z} \ln P_{i j} \times P_{i j}$

Low value of $E_{j}$ indicates a high effect of $j$ index.

Entropy weight $\left(W_{j}\right)$ of $j$ parameter can therefore be calculated with the formula below,

$W_{j}=\left(1-E_{j}\right) / \sum_{j=1}^{t}\left(1-E_{j}\right)$

Step 2-Assigning quality rating scale $\left(Q_{j}\right)$ for each parameter with the following formula:

$Q_{j}=\left(C_{j} / S_{j}\right) \times 100$

where $C_{j}$ is the concentration of each parameter in each sample, $S_{j}$ is the quality standard for ground water.

Step 3-Calculation of WQI using the following formula

$\mathrm{WQI}=\sum_{j=1}^{t} W_{j} Q_{j}$

WQI can be classified into five ranks as shown in Table 1 .

Correlation coefficient is used to measure the strength and the direction of a linear relationship between two variables. Correlation matrix was calculated for WQI and water quality parameters. Correlation matrix was generated with Microsoft Office Excel 2007 package. Values in the matrix were confirmed to be correct by manual calculation with the following formula:

$$
R=\frac{n \sum x y-\left(\sum x\right)\left(\sum y\right)}{\sqrt{\left[n\left(\sum x^{2}\right)-\left(\sum x\right)^{2}\right]} \sqrt{\left[n\left(\sum y^{2}\right)-\left(\sum y\right)^{2}\right]}}
$$

where $R$ is the linear correlation coefficient, $x$ and $y$ are the variables to be compared, $n$ is the number of variables. Correlation that is greater than 0.8 is described as strong while a correlation less than 0.5 is described as weak.

Accuracy of measurement

The closeness of the measured value to the accepted reference value is determined by calculating the accuracy of measurement. This can be obtained by subtracting the measured value from the accepted value and then divide

Table 1 Classification of water quality index

\begin{tabular}{lll}
\hline Rank & WQI & Water quality \\
\hline 1 & $<50$ & Excellent \\
2 & $50-100$ & Good \\
3 & $100-150$ & Average \\
4 & $150-200$ & Poor \\
5 & $>200$ & Extremely poor \\
\hline
\end{tabular}


Table 2 Computation of information entropy of parameters and WQI of sampling station AGGW1 (dry season 2008)

\begin{tabular}{|c|c|c|c|c|c|c|}
\hline \multirow[t]{2}{*}{ Parameter (Unit) } & \multirow[t]{2}{*}{ Standard value $(\mathrm{Si})$} & \multirow[t]{2}{*}{ Standard } & \multicolumn{3}{|c|}{ AGGW1 concentration } & \multirow[t]{2}{*}{ Accuracy of measurement (\%) } \\
\hline & & & Max & Min & Ave $(\mathrm{Ci})$ & \\
\hline $\mathrm{pH}$ & $6.5-8.5$ & WHO (1996) & 6.22 & 6.21 & 6.22 & 17.06 \\
\hline Conductivity (uS/cm) & 400 & Asonye et al. (2007) & 214.00 & 213.00 & 213.50 & 46.62 \\
\hline Turbidity (NTU) & 5 & Asonye et al. (2007) & 0.00 & 0.00 & 0.00 & \\
\hline $\mathrm{PO}_{4}{ }^{3-}(\mathrm{mg} / \mathrm{l})$ & 0.2 & Mohamad et al. (2007) & 0.06 & 0.04 & 0.05 & 75.0 \\
\hline $\mathrm{SO}_{4}{ }^{2-}(\mathrm{mg} / \mathrm{l})$ & 200 & WHO (1996) & 3.80 & 3.60 & 3.70 & 98.0 \\
\hline $\mathrm{N}-\mathrm{NO}_{3}{ }^{-}(\mathrm{mg} / \mathrm{l})$ & 10 & Mohamad et al. (2007) & 1.15 & 1.07 & 1.12 & 88.8 \\
\hline TDS (mg/l) & 1000 & WHO (1996) & 153.00 & 151.00 & 151.75 & 84.82 \\
\hline $\mathrm{Cl}^{-}(\mathrm{mg} / \mathrm{l})$ & 250 & USEPA (1996) & 18.80 & 16.80 & 17.75 & 92.9 \\
\hline Alkalinity $\left(\right.$ as $\left.\mathrm{CaCO}_{3}\right)(\mathrm{mg} / \mathrm{l})$ & $80-150$ & WHO (1996) & 54.00 & 50.00 & 52.00 & 54.78 \\
\hline Hardness $\left(\right.$ as $\left.\mathrm{CaCO}_{3}\right)(\mathrm{mg} / \mathrm{l})$ & 500 & WHO (1993) & 40.30 & 36.20 & 37.85 & 92.43 \\
\hline $\mathrm{Ca}^{2+}(\mathrm{mg} / \mathrm{l})$ & 75 & WHO (1982) & 13.90 & 12.30 & 12.75 & 83 \\
\hline $\mathrm{Mg}^{2+}(\mathrm{mg} / \mathrm{l})$ & 30 & WHO (1982) & 2.30 & 1.90 & 2.18 & 92.7 \\
\hline $\mathrm{Na}^{+}(\mathrm{mg} / \mathrm{l})$ & 200 & WHO (1982) & 6.10 & 6.00 & 6.04 & 96.8 \\
\hline $\mathrm{K}^{+}(\mathrm{mg} / \mathrm{l})$ & $0.6-10$ & WHO (1996) & 12.30 & 11.60 & 11.91 & 124 \\
\hline Total coliform (Conc/100 ml) & 5 & Stewart et al. (2009) & 0.00 & 0.00 & 0.00 & \\
\hline
\end{tabular}

the difference by the accepted reference value. The quotient is then multiplied by 100 to produce the percent error. The main objective of this research is either the measured value falls within an accepted reference value, or it is lower or higher than an accepted reference value.

\section{Results and discussion}

Tables 2 and 3 show the calculation of WQI from the concentrations of parameters for sampling station AGGW1 (Dry season 2008). The water quality index, concentrations of parameters of ground water and the calculated correlation coefficients are shown in Tables 4 and 5. Correlation matrix of WQI and parameters is shown in Table 6. Correlation coefficients in the correlation matrix can also be obtained manually as shown in Table 7 using the correlation coefficient formula (Eq. 8). Figure 2 shows the chart of WQI in the stations.

From Fig. 2, it was observed that in the rainy season of year 2008, sampling point AGGW4 was not accessible because it was covered up by River Oluwa, but in the rainy season of year 2009, it was accessible. Therefore, data for sampling station AGGW4 were not available in rainy season of year 2008. Also at the onset of this research, there was no borehole at Agbabu and Temidire farm settlements of Agbabu bitumen deposit area. As at the time of dry season sample collection in 2009, a borehole had been drilled at Agbabu farm settlement. Since borehole is considered as ground water, samples were therefore collected from the borehole sampling point $(\mathrm{AGBH})$ in the dry and rainy seasons of year 2009. WQI showed that the quality of the wells declined over the years when compared with the permissible limits of international standards. In the dry season of year 2008, only sampling station AGGWM2 was ranked 'extremely poor' while two sampling stations, AGGW1 and AGGW4, were ranked 'excellent'. The same trend was followed in the rainy season of the same year and the dry season of year 2009. However, three sampling stations, AGGW1, AGGW3 and AGGW4, were ranked 'extremely poor' in the rainy season of year 2009. The only station ranked 'excellent' in the rainy season of year 2009 is AGGW2. The borehole sampled was ranked excellent when first sampled but it was only ranked 'good' in the following sample collection. The most polluted ground water station was AGGWM2 at Temidire farm settlement, especially in the dry seasons. Sampling station AGGWM2 was highly polluted because it was not ringed and it was located very close to the house of the village chief. Therefore, domestic activities around the sampling point were very high especially in the dry seasons.

Correlation coefficient in this study was used to measure the strength and the direction of a linear relationship between WQI and the water quality parameters. It helped to explain the effects of the parameters on the WQI, that is, how the parameters affected the quality water. It was also used to explain the linear interaction between the parameters and how the relationship of the parameters affected the WQI. The correlation coefficient matrix of WQI and the parameters showed significant relationships between 
Table 3 Computation of information entropy of parameters in sampling station AGGW1 and WQI

\begin{tabular}{|c|c|c|c|c|c|c|c|c|}
\hline Parameter & $Y_{i j}$ & $P_{i j}$ & $P_{i j} \times \ln P_{i j}$ & $E_{j}$ & $1-E_{j}$ & $W_{j}$ & $Q_{j}$ & $W_{j} Q_{j}$ \\
\hline $\mathrm{pH}$ & 1.00 & 0.15 & -0.28 & 0.10 & 0.90 & 0.06 & 82.93 & 5.29 \\
\hline Conductivity & 0.50 & 0.07 & -0.19 & 0.07 & 0.93 & 0.07 & 53.38 & 3.52 \\
\hline Turbidity & 0.00 & 0.00 & 0.00 & 0.00 & 1.00 & 0.07 & 0.00 & 0.00 \\
\hline $\mathrm{PO}_{4}{ }^{3-}$ & 0.50 & 0.07 & -0.19 & 0.07 & 0.93 & 0.07 & 25.00 & 1.65 \\
\hline $\mathrm{SO}_{4}{ }^{2-}$ & 0.50 & 0.07 & -0.19 & 0.07 & 0.93 & 0.07 & 1.85 & 0.12 \\
\hline $\mathrm{N}-\mathrm{NO}_{3}{ }^{-}$ & 0.63 & 0.09 & -0.22 & 0.08 & 0.92 & 0.07 & 11.20 & 0.73 \\
\hline TDS & 0.38 & 0.06 & -0.16 & 0.06 & 0.94 & 0.07 & 15.18 & 1.01 \\
\hline $\mathrm{Cl}^{-}$ & 0.48 & 0.07 & -0.19 & 0.06 & 0.94 & 0.07 & 7.10 & 0.47 \\
\hline Alkalinity (as $\mathrm{CaCO}_{3}$ ) & 0.50 & 0.07 & -0.19 & 0.07 & 0.93 & 0.07 & 45.22 & 2.99 \\
\hline Hardness (as $\mathrm{CaCO}_{3}$ ) & 0.40 & 0.06 & -0.17 & 0.06 & 0.94 & 0.07 & 7.57 & 0.50 \\
\hline $\mathrm{Ca}^{2+}$ & 0.28 & 0.04 & -0.13 & 0.05 & 0.95 & 0.07 & 17.00 & 1.15 \\
\hline $\mathrm{Mg}^{2+}$ & 0.70 & 0.10 & -0.24 & 0.08 & 0.92 & 0.06 & 7.27 & 0.47 \\
\hline $\mathrm{Na}^{+}$ & 0.40 & 0.06 & -0.17 & 0.06 & 0.94 & 0.07 & 3.02 & 0.20 \\
\hline $\mathrm{K}^{+}$ & 0.44 & 0.07 & -0.18 & 0.06 & 0.94 & 0.07 & 224.72 & 14.92 \\
\hline Total coliform & 0.00 & 0.00 & 0.00 & 0.00 & 1.00 & 0.07 & 0.00 & 0.00 \\
\hline Sum & 6.70 & & & & 14.13 & & & 33.03 \\
\hline
\end{tabular}

Table 4 Water quality index and parameters of ground water

\begin{tabular}{|c|c|c|c|c|c|c|c|c|c|c|}
\hline Season/year & Sample ID & WQI & WQI rank & $\mathrm{pH}$ & Conductivity & Turbidity & $\mathrm{PO}_{4}{ }^{3-}$ & $\mathrm{SO}_{4}^{2-}$ & $\mathrm{N}-\mathrm{NO}_{3}{ }^{-}$ & TDS \\
\hline \multirow[t]{5}{*}{ Dry-2008 } & AGGW1 & 33.03 & 1 & 6.22 & 213.5 & 0 & 0.05 & 3.1 & 1.12 & 151.8 \\
\hline & AGGW2 & 50.41 & 2 & 4.13 & 279.5 & 10.25 & 0.17 & 9.08 & 0.87 & 197.3 \\
\hline & AGGW3 & 91.13 & 2 & 5.18 & 216.5 & 32.76 & 0.24 & 0 & 0.17 & 154.5 \\
\hline & AGGW4 & 33.47 & 1 & 5.71 & 106.5 & 7.25 & 0.23 & 0 & 0.66 & 77 \\
\hline & AGGWM2 & 312.87 & 5 & 6.47 & $1,006.25$ & 1.5 & 0.14 & 1.1 & 0.47 & 706.5 \\
\hline \multirow[t]{4}{*}{ Rainy-2008 } & AGGW1 & 42.41 & 1 & 7.2 & 315.7 & 0 & 0.24 & 4.12 & 1.9 & 221.5 \\
\hline & AGGW2 & 288.24 & 5 & 4.7 & 295.75 & 4.25 & 0.06 & 1.75 & 1.69 & 210 \\
\hline & AGGW3 & 34.27 & 1 & 6.64 & 201.5 & 0 & 0.15 & 1 & 0.98 & 142.5 \\
\hline & AGGWM2 & 61.77 & 2 & 7.04 & 621 & 0 & 0.1 & 1.77 & 0.26 & 435 \\
\hline \multirow[t]{6}{*}{ Dry-2009 } & AGGW1 & 215.79 & 5 & 6.43 & 209.33 & 0 & 0 & 0 & 1.75 & 146.3 \\
\hline & AGGW2 & 69.68 & 2 & 6.74 & 105.33 & 0.67 & 0 & 0 & 1.27 & 75.33 \\
\hline & AGGW3 & 37.90 & 1 & 7.68 & 3.16 & 1.67 & 0 & 1.03 & 2.18 & 224 \\
\hline & AGGW4 & 50.06 & 1 & 7.95 & 264.67 & 12.33 & 0 & 2.97 & 1.54 & 185.7 \\
\hline & AGGWM2 & 176.69 & 4 & 6.08 & 96.33 & 0 & 0 & 6.13 & 1.06 & 67.33 \\
\hline & AGBH & 15.79 & 1 & 7.39 & 188.33 & 0 & 0 & 0 & 0.82 & 132.7 \\
\hline \multirow[t]{7}{*}{ Rainy-2009 } & AGGW1 & 204.70 & 5 & 6.92 & 161.33 & 15.67 & 0 & 3.83 & 1.31 & 114.7 \\
\hline & AGGW2 & 21.09 & 1 & 6.96 & 153 & 0 & 0 & 1.83 & 1.16 & 108.7 \\
\hline & AGGW3 & 323.28 & 5 & 4.77 & 272.33 & 0 & 0 & 0 & 2.27 & 192.7 \\
\hline & AGGW4 & 244.42 & 5 & 7.07 & 345 & 0 & 0 & 4.83 & 2.61 & 241.7 \\
\hline & AGGWM2 & 146.58 & 3 & 7.29 & 736.33 & 0 & 0 & 4.17 & 1.71 & 518 \\
\hline & AGBH & 51.46 & 2 & 7.42 & 378.67 & 0.33 & 0 & 0 & 1.56 & 266.3 \\
\hline & & Corr. Coef & & -0.36 & 0.39 & -0.06 & -0.22 & 0.01 & 0.32 & 0.35 \\
\hline
\end{tabular}

WQI and total coliform (0.99) and moderate significant relationship with TDS, conductivity and $\mathrm{N}-\mathrm{NO}^{3-}$. High correlation between WQI and total coliform in the environment indicates high microbial activity in the environment because bitumen is formed when crude oil migrates to shallow depths on the margins of basins. It is attacked by bacteria which remove the light ends, leaving behind sticky viscous materials known as bitumen 
Table 5 Water quality index and parameters of ground water

\begin{tabular}{|c|c|c|c|c|c|c|c|c|c|}
\hline Season/year & Sample ID & $\mathrm{Cl}^{-}$ & Alkalinity (as $\mathrm{CaCO}_{3}$ ) & Hardness (as $\mathrm{CaCO}_{3}$ ) & $\mathrm{Ca}^{2+}$ & $\mathrm{Mg}^{2+}$ & $\mathrm{Na}^{+}$ & $\mathrm{K}^{+}$ & Total coliform \\
\hline \multirow[t]{5}{*}{ Dry-2008 } & AGGW1 & 17.75 & 52 & 37.85 & 12.75 & 2.18 & 6.04 & 11.91 & 0 \\
\hline & AGGW2 & 29.1 & 10.5 & 32.55 & 6.35 & 4.03 & 6.33 & 13.11 & 0 \\
\hline & AGGW3 & 42.68 & 17 & 24.33 & 7.93 & 1.1 & 7.2 & 4.75 & 15.5 \\
\hline & AGGW4 & 15.25 & 8.75 & 19.18 & 4.85 & 1.73 & 5.16 & 5.17 & 0 \\
\hline & AGGWM2 & 70.68 & 33.5 & 44.65 & 13.08 & 2.77 & 8.93 & 6.03 & 199.25 \\
\hline \multirow[t]{4}{*}{ Rainy-2008 } & AGGW1 & 56.55 & 12.75 & 45.48 & 12.95 & 3.03 & 2.83 & 12.43 & 0 \\
\hline & AGGW2 & 28.03 & 11.5 & 24.5 & 8.73 & 0.85 & 1.4 & 11.87 & 188.75 \\
\hline & AGGW3 & 44.45 & 23.75 & 21.48 & 0.79 & 1.85 & 1.23 & 6.23 & 5 \\
\hline & AGGWM2 & 174.3 & 43 & 28.98 & 4.65 & 3.95 & 1.19 & 6.04 & 17.08 \\
\hline \multirow[t]{6}{*}{ Dry-2009 } & AGGW1 & 49.27 & 11.67 & 17.5 & 6.17 & 0.87 & 4.5 & 6.24 & 146.67 \\
\hline & AGGW2 & 10.33 & 27.67 & 11.67 & 7.67 & 0.47 & 6.72 & 13.87 & 30 \\
\hline & AGGW3 & 39.27 & 66 & 26.2 & 9.17 & 0.93 & 8.7 & 6.55 & 8.67 \\
\hline & AGGW4 & 23.47 & 7.67 & 55.37 & 12.37 & 6.03 & 11.3 & 12.34 & 0 \\
\hline & AGGWM2 & 295.9 & 39.33 & 34.67 & 7.73 & 3.67 & 6.42 & 3.13 & 116.67 \\
\hline & AGBH & 44.07 & 16.33 & 13.27 & 0.87 & 2.87 & 2.56 & 1.47 & 0 \\
\hline \multirow[t]{7}{*}{ Rainy-2009 } & AGGW1 & 33.73 & 7.67 & 11.67 & 3.2 & 0.97 & 1.5 & 5.22 & 123.33 \\
\hline & AGGW2 & 21.67 & 3.93 & 7.63 & 4.7 & 0.53 & 1 & 6.75 & 0 \\
\hline & AGGW3 & 35.73 & 20.67 & 15.2 & 6.23 & 0.47 & 1.66 & 7.2 & 230 \\
\hline & AGGW4 & 37 & 41 & 42.8 & 6.33 & 5.93 & 3.5 & 6.45 & 163.33 \\
\hline & AGGWM2 & 133 & 21.33 & 30.8 & 12.2 & 0.47 & 5.32 & 19.76 & 70 \\
\hline & AGBH & 24.33 & 11.67 & 38.2 & 6.3 & 5.07 & 5.03 & 4.87 & 20 \\
\hline & Corr. Coef. & 0.15 & 0.01 & 0.02 & 0.16 & -0.15 & -0.11 & -0.04 & 0.99 \\
\hline
\end{tabular}

(World Energy Council 2007). Sources of coliform bacteria include: plants, soil, animals and humans. Apart from contamination by human factors, such as agriculture, washing, sewage and wastes, the presence of bitumen in the environment also contributed to high microbial activity observed. Bacteriological determination of quality in water has a long history. In 1912, Gartiner observed multiplication of bacteria on bitumen coating of water reservoir (Bali et al. 2002). It has also been reported that liner materials may contain bitumen, chlorinated rubber, epoxy resin, or tar epoxy resin combinations that can support bacterial growth (Schoenen 1986). In this research, total coliform values ranged from 'not detectable' to 230.00 conc/100 $\mathrm{ml}$. Most of the sampling points had values that are above 5 conc/100 $\mathrm{ml}$ recommended limit for drinking water (Stewart et al. 2009). High concentration of total coliform in the environment indicates high microbial activity due to the presence of bitumen. Coliforms do not generally cause illness, but high numbers of these bacteria in wells may mean that other disease causing bacteria are present (Whitman et al. 2006). High concentration of total coliform in most of the wells in the environment renders them unfit for human consumption unless properly treated.
Sampling station AGGWM2 had higher conductivity than the recommended level of $400 \mu \mathrm{S} / \mathrm{cm}$ in three out of four seasons considered. Correlation coefficient matrix showed significant relationships between TDSs and conductivity (0.96). This shows that conductivity was high due to high quantity of bitumen in the environment that stripped out in several places around the sampling point. Multi-elemental analysis carried of Agbabu bitumen carried out by Adebiyi et al. (2006) showed that the enrichment factor of $\mathrm{V}, \mathrm{Cr}, \mathrm{Ni}, \mathrm{Cu}, \mathrm{Zn}$, As and $\mathrm{Pb}$ were very high. The development of petroleum drilling activities has been reported to increase TDS in the Niger Delta (Ayotamuno et al. 2002). Therefore, high conductivity observed at sampling point AGGWM2 was due the presence of inorganic and organic salts present in bitumen.

The correlation coefficients showed significant relationships between total hardness and $\mathrm{Ca}^{2+}(0.68)$, and total hardness and $\mathrm{Mg}^{2+}(0.75)$. The correlation coefficients also showed moderate significant relationship between total hardness and $\mathrm{SO}_{4}{ }^{2-}(0.41)$. These showed that total hardness in the study area is permanent and cannot be removed by boiling. 


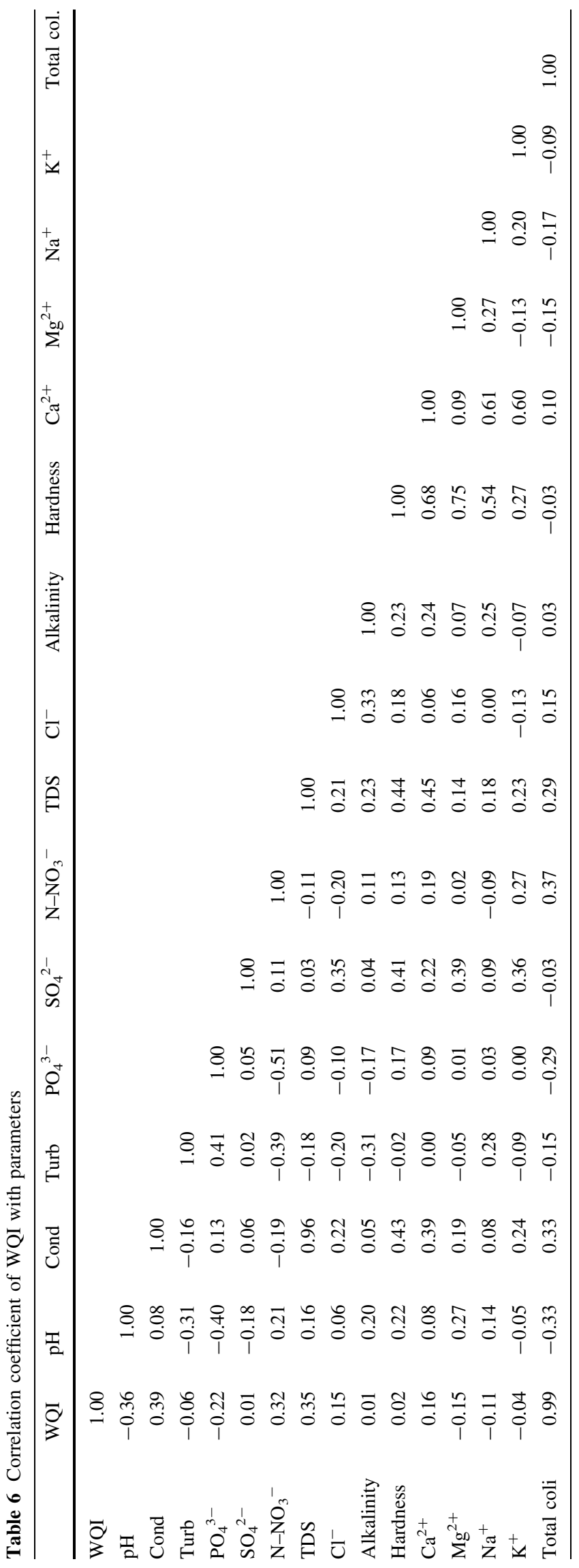


Table 7 Calculation of correlation coefficient of WQI with parameters

$0.38595006=R$ (Correlation coefficient)

Fig. 2 Chart showing WQI in the stations

\begin{tabular}{llllllll}
\hline & \multicolumn{1}{c}{ Total } \\
\hline WQI (X) & 33 & 50.41 & 91.13 & $\ldots$ & 146.58 & 51.46 & 2505.01 \\
Conductivity (Y) & 213.5 & 279.5 & 216.5 & $\ldots$ & 736.33 & 378.67 & 6170.01 \\
$x^{2}$ & 1089 & 2541.1681 & 8304.677 & $\ldots$ & 21485.70 & 2648.13 & 518377.12 \\
$y^{2}$ & 45582.3 & 78120.25 & 46872.25 & $\ldots$ & 542181.87 & 143390.97 & 2905753.01 \\
$X Y$ & 7045.5 & 14089.595 & 19729.65 & $\ldots$ & 107931.25 & 19486.36 & 925061.64 \\
\hline
\end{tabular}

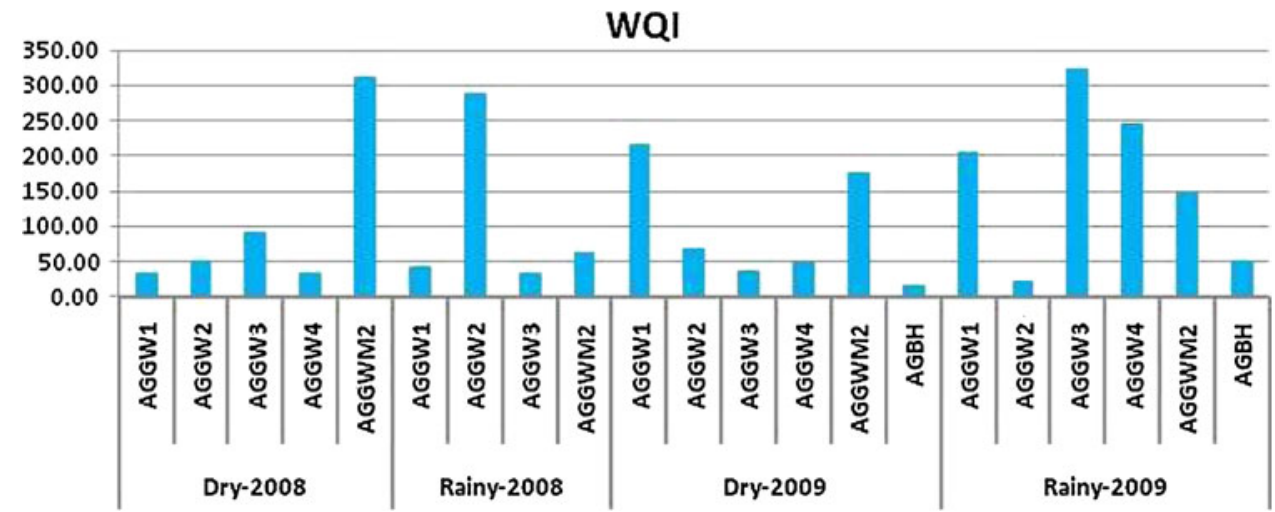

Values of $\mathrm{pH}$ in the study area ranged from 4.13 to 7.95 as shown in Tables 2 and 4 . The recommended $\mathrm{pH}$ for domestic and drinking water is 6.5-8.5 (WHO 1996). Therefore, the values of $\mathrm{pH}$ obtained at sampling stations AGGW1, AGGW2, AGGW3, AGGW4, AGGWM2 (dry season 2008), AGGW2 (rainy season 2008), AGGW1, AGGW2 (dry season 2009), and AGGW3 (rainy season 2009) were lower than recommended. Correlation coefficients showed moderate significant relationship between $\mathrm{pH}$ and total coliform, $\mathrm{pH}$ and phosphate ion, $\mathrm{pH}$ and turbidity. The shows that $\mathrm{pH}$ of hand dug wells were low due to domestic activities around the wells which were usually higher in the dry seasons.

Conductivity ranged from $3.16 \mu \mathrm{S} / \mathrm{cm}$ at sampling point AGGW3 (dry season 2009) to $1006.25 \mu \mathrm{S} / \mathrm{cm}$ at AGGWM2 (dry season 2008) as shown in Table 2. The guide limit of water conductivity is $400 \mu \mathrm{S} / \mathrm{cm}$ (Asonye et al. 2007). Therefore, conductivity at sampling point AGGWM2 at Temidire farm settlement were very high in both dry and rainy seasons of year 2008 and dry season of year 2009 while conductivity in the remaining stations were within the guide limit. High conductivity in this station indicates the presence if high inorganic pollutants such as dissolved salts and heavy metals. Ten heavy metals ( $\mathrm{Fe}$, $\mathrm{Cu}, \mathrm{Mn}, \mathrm{Cr}, \mathrm{Zn}, \mathrm{Hg}, \mathrm{Pb}, \mathrm{Cd}, \mathrm{N}_{\mathrm{I}}$, and $\mathrm{V}$ ) were analyzed in surface and ground water samples collected from Temidire village at Agbabu bitumen deposit area in the dry and rainy seasons of year 2008 using Atomic Absorption Spectrometry. In the dry season, all the stations except $\mathrm{Mn}$ in Temidire in surface and ground water had concentrations of $\mathrm{Cr}$ and $\mathrm{Mn}$ that were higher than WHO recommendations for potable water. Speciation of heavy metals $\mathrm{Cu}, \mathrm{Cd}$, $\mathrm{Pb}, \mathrm{Ni}, \mathrm{Zn}, \mathrm{Mn}, \mathrm{Fe}, \mathrm{Cr}$ and $\mathrm{Hg}$ was carried out on sediment of Agbabu bitumen deposit area, which includes Temidire, with a sequential extraction procedure in the dry and rainy seasons of year 2008. The average potential mobility was calculated for the metals in the two seasons and the following decreasing order was obtained: $\mathrm{Cr}>\mathrm{Zn}>\mathrm{Cu}>$ $\mathrm{Mn}>\mathrm{Fe}>\mathrm{Cd}>\mathrm{Ni}>\mathrm{Pb}>\mathrm{Hg}$ (Fagbote and Olanipekun 2010b). This sampling station was located in Temidire village where there were more stripping of bitumen compared with other villages. Therefore, high conductivity observed here arose due to contamination of water in the environment with heavy metals from bitumen. Another probable cause of high conductivity here was agricultural activities in the village.

In ground water in the study area, the highest turbidity observed was $32.76 \mathrm{NTU}$ obtained at AGGW3 (dry season 2009) while it was not detectable in some stations. Values of turbidity in some of sampling station were higher than 5 NTU recommended for drinking water (Asonye et al. 2007), due to high domestic activities such as washing. Turbidity can increase in ground water due to domestic activities, waste products and re-suspended sediment from the bottom. During the rainy season, there were less domestic activities around the wells because the villagers now had access to water for domestic use from many sources including rain water. In addition, the volume of water in the wells was more and there were less re-suspended sediment from the bottom of the wells even when 
the water was stirred during collection. Therefore, values of turbidity obtained in the rainy seasons in this study were lower than the ones obtained in the dry season. Some of the values in the rainy seasons were even not detectable.

In ground water in the study area, phosphate $\left(\mathrm{PO}_{4}{ }^{3-}\right)$ values were from 'not detectable' to $0.24 \mathrm{mg} / \mathrm{l}$ at sampling stations AGGW3 (dry season 2008) and AGGW1 (rainy season 2008). Unpolluted streams have phosphate level of $0.01 \mathrm{mg} / \mathrm{l}$ (General Fact Sheet on Water Quality Parameters 2003). Therefore, all stations sampled in year 2008 showed signs of pollution with phosphate probably due to domestic activities, such as the use of detergents for laundry. Phosphate concentrations were 'not detectable' in year 2009 probably due to reduction in domestic activities around the hand dug wells. Domestic activities around the wells were shifted to the newly drilled borehole. High concentrations of phosphate indicate the presence of pollution and leads to reduction in dissolved oxygen in water bodies (Riyad et al. 2006).

The minimum alkalinity was $3.93 \mathrm{mg} / \mathrm{l}$ at sampling station AGGW2 (rainy season 2009) and the maximum was $66.0 \mathrm{mg} / \mathrm{l}$ at sampling station AGGW3 (dry season 2009). This means water's ability to neutralize acids or act as a buffer to keep the $\mathrm{pH}$ constant. Water bodies with an alkalinity above $20 \mathrm{mg} / \mathrm{l}$ have some resistance to acid impacts, but a more desirable range is $80-150 \mathrm{mg} / \mathrm{l}$. Alkalinity obtained in this study were all lower than the recommended range.

$\mathrm{K}^{+}$values were from $1.47 \mathrm{mg} / \mathrm{l}$ at sampling station AGBH (dry season 2009) to $19.76 \mathrm{mg} / \mathrm{l}$ at AGGWM2 (rainy season 2009). The recommended concentration of $\mathrm{K}^{+}$in drinking water is $0.6-10 \mathrm{mg} / \mathrm{l}$ (WHO 1996). Sampling point AGGW2 has $\mathrm{K}^{+}$concentration above the recommended value throughout the seasons except rainy season of year 2009. This is probably due to the proximity of the sampling point to bitumen well NBC-7. Multi-elemental analysis of Nigerian bitumen and the physical constants characterization of its hydrocarbon content carried out by Adebiyi et al. (2006), revealed that Agbabu bitumen contains $\mathrm{K}, \mathrm{Ca}, \mathrm{Ti}, \mathrm{V}, \mathrm{Cr}, \mathrm{Mn}, \mathrm{Fe}, \mathrm{Ni}, \mathrm{Cu}, \mathrm{Zn}, \mathrm{As}$ and $\mathrm{Pb}$.

Sulphate $\left(\mathrm{SO}_{4}{ }^{2-}\right)$ was 'not detectable' at sampling stations AGGW3 (dry season 2008), AGGW4 (dry season 2008), AGGW1 (dry season 2009), AGGW2 (dry season 2009), AGBH (dry season 2009), AGGW3 (rainy season 2009) and AGBH (rainy season 2009). The maximum value of $9.08 \mathrm{mg} / \mathrm{l}$ was obtained at sampling station AGGW3 (dry season 2008). Values obtained were below the recommended limits of $200 \mathrm{mg} / \mathrm{l}$ (WHO 1996). Although sulphate is classified as a non-toxin, intake of its ions at elevated concentrations can cause diarrhoea (Faniran et al. 2001).
The minimum $\mathrm{N}-\mathrm{NO}_{3}{ }^{-}$value obtained in this study was $0.17 \mathrm{mg} / \mathrm{l}$ at sampling station AGGW3 (dry season 2008), while the maximum was 2.61 at sampling station AGGW4 (rainy season 2009). These values were below $10 \mathrm{mg} / \mathrm{l}$ which is the concentration above which $\mathrm{N}-\mathrm{NO}_{3}{ }^{-}$becomes toxic to animals in water.

The minimum $\mathrm{Mg}^{2+}$ value in this study was $0.47 \mathrm{mg} / \mathrm{l}$ at sampling stations AGGW2 (dry season 2009), AGGW3 (rainy season 2009) and AGGWM2 (rainy season 2009). The maximum value obtained was 5.93 at AGGW4 (rainy season 2009). These values were below the maximum level of $30 \mathrm{mg} / \mathrm{l}$ allowed in drinking water (WHO 1982).

$\mathrm{Na}^{+}$values were from $1.0 \mathrm{mg} / \mathrm{l}$ at sampling station AGGW2 (rainy season 2009) to $11.3 \mathrm{mg} / \mathrm{l}$ at sampling point AGGW4 (dry season 2009). The values obtained in this study were below the maximum level of $200 \mathrm{mg} / \mathrm{l}$ allowed in drinking water (WHO 1982).

Conductivity, $\mathrm{pH}$, turbidity, phosphate ions and total coliform values obtained in some wells were out of the recommended range for drinking water. TDS, sulphate, nitrogen nitrate, chloride, alkalinity, total hardness, calcium, magnesium, sodium and potassium had values that were within the recommended range for drinking in all the stations. Generally, in water quality ranking, WQI less than 50 is considered 'excellent', WQI from 50 to 100 is considered 'good', WQI from 100 to 150 is considered 'average', WQI from 150 to 200 is considered 'poor' and WQI above 200 is considered 'extremely poor'. WQI of the wells when compared with the permissible limits of international standards, ranked the bore hole at Agbabu as 'excellent' in the dry season of year 2009 and just 'good' in the rainy season of the same year. Sampling stations of ground water in the study area were ranked extremely poor at least once out of the four seasons considered.

\section{Conclusion}

The quality of ground water in the study area declined over the years. The most polluted ground water station was AGGWM2 at Temidire farm settlement, especially in the dry seasons.

High correlation between WQI and total coliform in the study area indicates high microbial activity in the environment. Other sources of coliform bacteria include plants, soil, animals and humans. Apart from contamination the presence of bitumen in the environment, by human factors must have also contributed to high microbial activity observed. High concentration of total coliform in most of the shallow wells in the environment, due to the presence of bitumen, renders them unfit for human consumption unless properly treated. 
Commencement of exploitation of bitumen in the environment is expected to pollute ground water more. Therefore, data obtained in this study can be used as reference data to monitor pollution in the study area.

Acknowledgments The authors which to express their gratitude to the Department of Chemistry, University of Ado-Ekiti, Ado-Ekiti, Nigeria and the management of the University of Ado-Ekiti, Nigeria, for their support.

\section{References}

Abulude FO, Obidiran GO, Orungbemi S (2007) Determination of physico-chemical parameter and trace metal contents of drinking water samples in Akure Nigeria. Electronic J of Environ, Agric and food Chem 6(8):2297-2303

Adebiyi FM, Asubiojo OI, Ajayi TR (2006) Multi-elemental analysis of Nigerian bitumen by TXRF spectrometry and the physical constants characterization of its hydrocarbon content. Fuel 85(3): $396-400$

Adegoke OS, Ibe EC (1982) The tar sand and heavy crude resources of Nigeria. Proc 2nd Intern Conf on heavy crude and Tarsands, Caracas, Venezuela, chapter 32, 280-285

Adewole MO (2010) Environmental implications of bitumen seep induced pollution in parts of Ogun state, southwestern Nigeria. Environ Earth Sci 59:1507-1514

Akinmosin A, Osinowo OO, Oladunjoye MA (2009) Radiogenic components of the Nigeria Tarsand deposits. Earth Sci Res J 13(1):64-73

American Public Health Association-APHA (1985) Standard methods for the examination of water and wastewater, Washington. http://www.h2oc.com/pdfs/Kinetics-Figures.pdf. Accessed 12/July/2010

Asonye CC, Okolie NP, Okenwa EE, Iwuanyanwu UG (2007) Some physico-chemical characteristics and heavy metal profiles of Nigerian rivers, streams and waterways. Afr J Biotechnol 6(5): 617-624

Atulegwu PU, Njoku JD (2004) The impact of biocides on the water quality. Int Res J Eng Sci Technol 1:47-52

Ayotamuno MJ, Akor AJ, Igho TJ (2002) Effluent quality and wastes from petroleum drilling operations in the Niger Delta Nigeria. J Environ Manag Health 13(2):207-216

Bali G, Ramamurthi RS, Sullia SB, Shivalipour A, Kastury S (2002) Environmental Biotechnology, ISBN 8176483788. SB Nangia, APH Publishing Corporation, New Delhi, p 98

Bhardwaj RM (2005) Water quality monitoring in India achievements and constraints, IWG-Env, International Work Session on Water Statistics, Vienna, pp 1-12

Cobbina SJ, Anvyidoho LY, Nyame F, Hodgson IO (2009) Water quality status of dugouts from five districts in Northern Ghana: implications for sustainable water resources management in a water stressed tropical savannah environment. Environ Monit Assess 167(1-4):405-416

Collins CH, Lyne PM (1980) Microbial methods. Butterworth and Co., Limited, London, pp 125-300

Fagbote EO, Olanipekun EO (2010a) Speciation of heavy metals in soil of bitumen impacted area of Western Nigeria. Eur J Sci Res 47(2):265-277

Fagbote EO, Olanipekun EO (2010b) Speciation of heavy metals in sediment of bitumen deposit area, Nigeria. J Appl Sci Environ Manage 14(4):5-11
Faniran JA, Ngceba FC, Bhat RB, Oche CY (2001) An assessment of the water quality of the Isinuka springs in the Transkei region of the Eastern Cape, Republic of South Africa. Water SA 27(2): 241-250

General Fact Sheet on Water Quality Parameters (2003) Monitoring the health of the watershed. Appendix D. Delaware River Keepers. http://www.dec.ny.gov/docs/water_pdf/jan09crotontmdl. pdf. Accessed 14/Jan/2010

Gruickshank R, Duguid JP, Marmion BP, Swain RHA (1984) Medical microbiology, 13th edn. Vol 2. Churchill Living Stone, New York. pp 170-189

Mohamad RMK, Mohd KY, Wan NA, Mat YA (2007) Creation of ground water quality index for an open municipal landfill area. J Math Sci 1(2):181-192

Oboh OB, Ilori MO, Akinyemi JO, Adebusoye SA (2006) Hydrocarbon degrading potentials of bacteria isolated from a Nigerian bitumen (Tarsand) deposit. Nature Sci 4(3):51-57

Oguntimehin II, Ipinmorroti KO (2007) Solvent extraction of vanadium from Nigerian bitumen using Tri-butylphosphate. J Applied Sci 7(24):4028-4031

Olajire AA, Alade OA, Adeniyi AA, Olabemiwo MO (2007) Distribution of polycyclic aromatic hydrocarbons in surface soils and water from the vicinity of Agbabu bitumen field of Southwestern Nigeria. J Environ Sci Health, Part A, 42(8): 1043-1049

Olajire AA, Olojubade M, Olabemiwo O (2008) n-Alkanes distributions in soil and water samples collected near Agbabu bitumen field of southwestern Nigeria. Int J Environ Stud 65(6):769-779

Pei-yue L, Hui Q, Jian-hua W (2010a) Ground water quality assessment based on improved water quality index in Pengyang County, Ningxia, Northwest China. E-J Chem, 7(S1):S209-S216

Pei-yue L, Hui Q, Jian-hua W (2010b) Ground water quality assessment based on entropy osculating value method. Int $\mathrm{J}$ Environ Sci 1(4):621-630

Riyad M, Mohammed R, Mohammed IB (2006) Relationship between water, temperature, nutrients and dissolved oxygen in the northern Gulf of Aqaba, Red sea. Oceanologia 48(2):257-263

Schoenen D (1986) Microbial growth due to materials in drinking water systems. In: Rehn HJ, Reed G (eds) Biotechnology, chap 20. VCH Publishers, Weinheim, pp 627-647

Stewart JC, Lemley AT, Hogan SI, Weismiller RA, Hornsby AG (2009) Drinking water standards, University of Florida, Institute of food and agricultural sciences (IFAS) extension. http//www. edis.ifas.nfl.edu.ss297. Accessed on 08/June/2011

Tanriverdi C, Alp A, Demirkiran AR, Uckardes F (2009) Assessment of surface water quality of the Ceyhan Rivan basin, Turkey. Environ Monit Assess 167(1-4):175-184

United States Environmental Protection Agency-USEPA (1996) Quality criteria for water. EPA 440/5-86-001, Washington Publication. http://www.epa.gov/waterscience/pc/wqnews/dec96.html. Accessed 02/Feb/2008

Veljkovic N, Lekic D, Jovicic M (2008) Case study of water management processes: Serbian water quality index. u: conference of the Danubian countries on the hydrological forecasting and hydrological bases of water management (XXIVth), Slovenia

Whitman RL, Nevers BM, Byappanahali MN (2006) Examination of the watershed-wide distribution of the Escherichia coli along Southern Lake Michigan: an integrated approach. Appl Environ Microbiol 72(11):7301-7310

World Energy Council (2007) Survey of energy resources. WEC London. Publication accessed online at http://web.mit.edu/mission/ www/m2013/ser_interim_update_2009_final.pdf on 17/Feb/2010

World Health Organization-WHO (1982) World health organization. Guideline for drinking water quality. WHO Geneva. http:// 
whqlibdoc.who.int/publications/9241545356.pdf. Accessed 18/Oct/ 2007

World Health Organization-WHO (1993) Guidelines for drinking water quality. World health organisation, Geneva. http://www. who.int/water_sanitation_health/dwq/fulltext.pdf. Accessed 12/ Aug/2009
World Health Organization-WHO (1996) Guidelines for drinking water quality. Vol 3. Geneva. http://www.who.int/water_sanitation_ health/dwq/GDWQ2004web.pdf. Accessed 12/Aug/2009

Yisa J, Jimoh T (2010) Analytical studies on water quality index of River Ladzu. Am J Appl Sci 7(4):453-458 